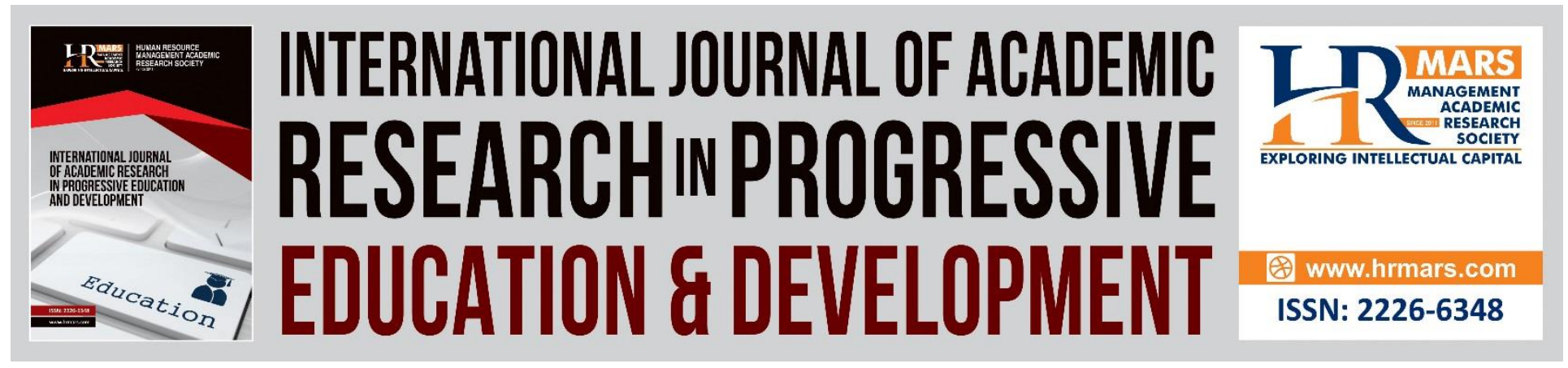

\title{
Exercising Democracy in Language Assessment: Preliminary Survey for Language and Literature Classrooms in Indonesian Context
}

\section{Ali Mustofa}

To Link this Article: http://dx.doi.org/10.6007/IJARPED/v7-i1/3901

DOI: $10.6007 /$ IJARPED/v7-i1/3901

Received: 12 Feb 2018, Revised: 16 Mar 2018, Accepted: 19 Mar 2018

Published Online: 22 Mar 2018

In-Text Citation: (Mustofa, 2018)

To Cite this Article: Mustofa, A. (2018). Exercising Democracy in Language Assessment: Preliminary Survey for Language and Literature Classrooms in Indonesian Context. International Journal of Academic Research in Progressive Education and Development, 7(1), 55-62.

\section{Copyright: (c) 2018 The Author(s)}

Published by Human Resource Management Academic Research Society (www.hrmars.com)

This article is published under the Creative Commons Attribution (CC BY 4.0) license. Anyone may reproduce, distribute, translate and create derivative works of this article (for both commercial and non-commercial purposes), subject to full attribution to the original publication and authors. The full terms of this license may be seen

at: http://creativecommons.org/licences/by/4.0/legalcode

\section{Vol. 7, No. 1, January 2018, Pg. 55 - 62}

Full Terms \& Conditions of access and use can be found at http://hrmars.com/index.php/pages/detail/publication-ethics 


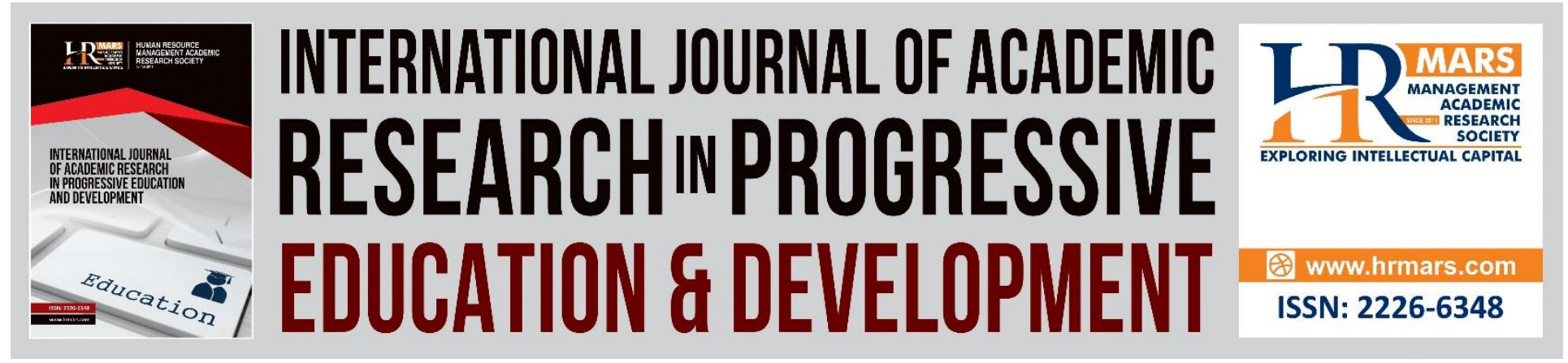

\title{
Exercising Democracy in Language Assessment: Preliminary Survey for Language and Literature Classrooms in Indonesian Context
}

\author{
Ali Mustofa \\ English Language and Literature Department, Faculty of Languages and Arts \\ Universitas Negeri Surabaya, Indonesia \\ Email: alimustofa@unesa.ac.id
}

\begin{abstract}
The paper explores the role model of assesment in language classrooms named as democratic assesment. Democratic assessment encourages peer-assessment and self-assessment as well as teacher-assessment. Some case studies are synthesized here to show the nature of this so-called role model of assesment. It draws students into personal participation in the evaluation process. Democratic assessment is also characterized by transparency. Such explanations may be accompanied by a scoring rubric, checklist, or other assessment tool as well as samples of students work from previous semesters. The discussion has shown that democratic teachers have the responsibility to assess whether their students have acquired the target skills and concepts and to coach them in areas where they are weak. The discussion has also figured out that democratic teachers, as autocratic teachers, retain the right to the respect of their students; in democratic environments, the students bestow such honor freely and without reservation upon teachers who have earned their respect.

Keywords: Model Of Assesment, Democratic Assesment, Transparancy, Authoritative Teachers

\section{Introduction}

Literary teaching has many problems since it has become a part of language teaching in universities in Indonesia. When it comes to the curriculum and its implementation, the teaching of literature has some constraints due to language competency for the students, and, pedagogical knowledge for the teachers as well. Besides, literary teaching also opens some problems when it has to deal with historical background where the works were written, cutural and social gaps between readers and writers, philosopical issues the writer wants to share, and psychological context in which the works tend to disclose (Mustofa, 2016). Another case related to literary teaching also addresses the need of the proper materials which should be provided to
\end{abstract}


DEVELOPMENT

Vol. 7, No.1, January 2018, E-ISSN: 2226-6348 @ 2018 HRMARS

meet the requirements as stated in the curriculum. It all begins with the fact that, in Indonesian context, English is a second language for the teachers and the learners.

In literature teaching, the problem often would not be as frustrated as in other teaching subjects, since literature materials are varied and are easily provided both online and offline. But the most difficult thing to bear is the assesment. In literature teaching, the scoring is not as simple as that of other subjects in language classrooms. It involves many aspects which should be taken into consideration. Many research of assessment in literary classroom have shown that democratic athmosphere of assessment will be resulting better climate of classroom management and achievement (Shohamy, 2001; Spigelman, 2005; Iberri-Shea 2009; Oscarson 2009; Tully 2009; Zakian, Moradan, \& Naghibi 2012). The paper explores the nature of democratic assessment in literature teaching as has been practiced in Indonesian classroom contexts due to some reasons that English is not the first language, and therefore there must be some consideration of agreement and negotiation between teachers and students to reach the goal of the teaching and learning.

\section{Theoretical Framework}

\section{What is Democratic Assesment?}

What would a democratic assessment practice look like? A classical refference which was firstly introduced by John Dewey (1903) has put, "... democracy means freeing intteligence for independept effectiveness-the emancipation of mind as an individual organ to do its own work. We naturally associate democracy, to be sure, with freedom of action, but freedom of action without freed capacity of thought behind it is only chaos" (Dewey, 1903). In practicing democracy, there will be an act to free the intelligent minds to work the independent effectiveness, that is how the minds of the intelligents to take side and to dedicate their minds to work of their own. And of course that the work should be based on freedom of action using the stated or mandated regulation. Just as in a democratic government, the people have a voice. In democratic assessment, the students have a voice too. However, every action should be in line with the regulation which has been determined before.

In literature classes, democratic assessment encourages peer-assessment and selfassessment as well as teacher-assessment. It draws students into personal participation in the evaluation process. In time, students regard themselves as knowledgeable, and rightly so, which empowers them to be competent, independent learners. Involving students a voice in the process of evaluation, in this sense, will also compel them to listen to their classmates (IberriShea 2009). It can be noticed that by the so called action, the objective result of evaluation will be manifested.

Democratic assessment is also characterized by transparency. Before the students begin their project, the teacher explains the criteria for evaluation to the students, making their expectations for student work and performance, for example in poem reading and drama performance, as explicit as possible. Such explanations may be accompanied by a scoring rubric, checklist, or other assessment tool as well as samples of students work from previous semesters. It should be taken into consideration that that democratic assessment will not be readily embraced by all English teachers, especially in literature classes. It is because some, and probably most of literature teachers, still enjoy to practice the classical ways of teaching; lecturing the concepts of major terms in literary studies and the syntactic structure of works, explaining some 
INTERNATIONAL JOURNAL OF ACADEMIC RESEARCH IN PROGRESSIVE EDUCATION AND DEVELOPMENT

Vol. 7, No.1, January 2018, E-ISSN: 2226-6348 @ 2018 HRMARS

ideas from the novels, reciting the verses of classical poems, and inventing the beauty of classical English drama.

Some out of courtesy may smile and praise the idea of bringing democracy to the language and literature assessment process, but in their heart of hearts, they have serious objections, particularly regarding teachers' authority, the reliability of students' evaluations, time constraints, and curricular support. In a spirit of democracy, it should be addressing these objections both with evidence from research and with anecdotes from teachers' own experiences of using democratic assessment in a predominantly autocratic teaching culture.

\section{Teacher Authority}

Some teachers object to democratic assessment practices because they think that such practices violate the rights and responsibilities due them. In the practice of democratic assessment, teachers may give up some rights and responsibilities, but in doing so, they assume much greater responsibilities. Traditionally, teachers of literature classes have held a very powerful, responsible role in the classroom. Their students have, for the most part, recognized them as the fount of knowledge. These students have also acknowledged that the teacher has certain rights in the classroom, among them, the right to assign grades to their work. In some cultures, the marks are uncontested because on the rare occasions when students have questioned the teacher, they have found that their score suffered.

Often, in literary classrooms, an autocratic teacher evaluates students' projects and gives them scores in accordance to the standard used by the school system. The teacher returns the projects to the student without any feedback. Students are frustrated because they have no idea of the criteria that was used to assess their performance, for example in poem and drama analysis. This practice needs to be challenged. Teachers in these autocratic classrooms may perceive that a democratic assessment process undermines their authority in the classroom. After all, if students have a voice in how their work is assessed, would that not give students the impression that they could question their teacher's assessment? Abdicating their right to arbitrarily assign grades to the students' work does, without question, relinquish some of the control of students' learning to the learners themselves. In this sense, the students need to get involved in the process of assesment. They have their voices to asses their own performances, as well as their peers' performances. By this, the teacher could reluctantly give feedback to students' performance, and put the score into the record book.

Whereas it is true that democratic assessment empowers students to question their teacher, it should be noted the nature of students' questions about assessment is quite different than that of the few brave students who would challenge an autocratic teacher. Students who have been involved defining the standard, want to understand how to reach the goal. Their interest in the number is only as it reflects their ability in doing so. Since adopting a democratic assessment process, it is experienced that fewer students challenged their scores at the end of the term.

Before the students begin their project, the teacher explains the criteria for evaluation to the students, making their expectations for student work and performance as explicit as possible. In the practice of democratic assessment, teachers may give up some rights and responsibilities, but in doing so, they assume much greater responsibilities. Democratic teachers retain the right and responsibility of being a model of the behavior that their students. These kind of teachers have a responsibility to make sure that their students understand what skills or concepts they 
Vol. 7, No.1, January 2018, E-ISSN: 2226-6348 @ 2018 HRMARS

need to learn and how their mastery of those will be evaluated. By doing so, these teachers have the responsibility to listen to their students to ascertain their interests and goals. Those teachers, once again, have the responsibility to assess whether their students have acquired the target skills and concepts and to coach them in areas where they are weak. They, as autocratic teachers, retain the right to the respect of their students; thus in democratic environments, the students bestow such honor freely and without reservation upon teachers who have earned their respect.

From that on, the teacher should be the role model in literature classroom. Being a good model for students in the classroom will promote better atmosphere. Students of course will look up to their teachers in the matters of imitating and self recognition. It is important for the authoritative teacher to expose positive attitude and behavior toward the students. A good authoritative teacher will promote positive comments or rewards to his/her pupils when they have carried out well on homework assignments/tasks or exhibited positive behaviors in class. This will produce better result in giving objective points of view over a case being investigated.

The situation will be much more different, however, with that of a class handled by a non authoritative teacher. An authoritative teacher is open to feedback, interaction and debates. A non authoritative teacher will not be an open individual to give respond to students' complaints. $\mathrm{He} /$ she will not accept any debate or different opinions. When a problem arises in a discussion, for example in discussing of any sensitive issues of same sex marriage, within a chapter in contemporary popular writer, it is important for the students to explore their limits and choices and use their own judgments rather than compelling what their teacher has said about the cases. An authoritative teacher, on the other hand, will motivate the students to talk freely without any fear of being rejected. The students can outlet and modify their thoughts and feelings openly without any barrier both from the teacher and their peers as well.

In a class by a non authoritative teacher, everything is decided by this kind of teacher, and the students do not have enough space to collaborate and share their ideas to achieve any goal. Significantly, as has been suggested by the pedagogical instruction, students should be situated to feel comfortable making questions or giving comments when they are hoped to be democratic. An authoritative classroom, in fact, offers students a chance to develop better communication skills for they have enough time and space to recreate what has been represented by the works they read, and also the insights their teacher has exposed to as a problem to discuss.

\section{Method}

The paper applied literature review by which the discussion was carried out to explore the nature of democratic assessment in literary classrooms. I have been involved and witnessed that for several years language and literature classrooms have tested on better technique of evaluation for the improvement of ease-free evaluation. I should say that democratic assessment has been helpful in determining the students' scoring in both mid term and final term, since the evaluation also involves some different projects and methods. This kind of assessment which also involves the students' participation in giving the evaluation has also been approved objective since it is requiring bias-free as well as opennes to all members in the classroom. In discussing the topic, I will involve many different perceptions and perspectives as well to open up a fruitful discussion, and also to analyze the case in the context of EFL/ESL in Indonesian context generally. Problem solving method will be offered to critically point out every single case in the classroom situation. 
INTERNATIONAL JOURNAL OF ACADEMIC RESEARCH IN PROGRESSIVE EDUCATION AND DEVELOPMENT

Vol. 7, No.1, January 2018, E-ISSN: 2226-6348 @ 2018 HRMARS

\section{Discussion}

\section{Reliability of Students' Evaluation}

It can be stated that it is not easy to involve students in democratic assessment. It is because many teachers believe, "... that students cannot provide reliable results when evaluating the performance of their peers or themselves" (Mustofa, 2016). The validity and reliability of students' assessment is even questionable. However, this cannot be generalized and drawn into conclusion. Students need to be guided and reoriented in doing so (Oscarson 2009; Zakian, Moradan, \& Naghibi 2012). This should be done regularly and continously with the support of the teachers by giving feedback and reinforcement. Later on the students will be situated in the position as the performer and also as the evaluator respectively, and in return they soon accept that the habit will be generating democratic attitude.

Students will later on realize that the situation will lead them to think critically when they notice some unacceptable actions from their peers. This should also be noticed that their critical evaluation over a matter is a result of their being independent and autocratic. The possible impact should also be negotiated both by the students and the teachers, because when there were some heated arguments over a case, the teacher still need to pose him/hersel as a judge. In literature based classrooms, every discussion will lead to a conflicting ideas which also touch another consequence of debate and battle of argument. It is realized that in this kind of classroom, the relation of power among students exist (Shohamy, 2001; Spigelman, 2005). Spigelman even called on this as a paradox in democratic classroom. Both teacher and students are not free valued since they have their own problems dealing with the preparedness.

Giving an opportunity to students to give a voice in the assessment process challenges them to analyze their own performance and limits. The teachers should be able to lead them to be critical to their own performance, since this will develop an autonomy (Tully 2009). By giving the students the opportunities to freely make any judgment upon special issues such as how other student's a paper looks or how their classmate's reorientation distracted the audience from the point of discussion in a sharing session, for example, the teacher promotes the democratic process of how to respect other's evaluation. This of course will make students to identity and to prepare their own voices and to freely make use of them.

\section{Time Constraints}

Some teachers may object to the use of democratic assessment because discussing rubrics and giving feedback to every student, especially in large classes, would take too much time. While doing grammar drills, students are simply going through the motion of learning, not really using language for authentic purposes. By giving students tasks and goals, the teacher provides a means using the language for real purposes (Lytovchenko, 2009). This temporary conclusion may provide different assumption for different teachers. An autocratic teacher will provide his/her students to explore their limits to make use of the language for any real purpose. He/she will give the students enough space to organize and modify the language not only to express their ideas, but also to communicate them.

A change from autocracy to democracy in grading practice has several advantages for the language learning process. Democratic assessment practices encourage teachers and students to collaborate in dynamic ways so that cooperative teaching and learning activities are accessible 
DEVELOPMENT

Vol. 7, No.1, January 2018, E-ISSN: 2226-6348 @ 2018 HRMARS

to the students. Allowing students choices gives them some control over their learning (IberriShea 2009). In short, democratic language teaching provides better platform in breaking the iceberg of language teaching methodology. It promotes better performance in making the students and the teacher collaborate each other to successfully carry out the missions of teaching and learning a language communicatively. Democratic assessment is one of the models of assessment provided in the current language teaching issues and paradigms.

\section{Curricular support}

Some teachers may object to democratic assessment because the school's English curriculum does not support it. After all, the books already clarify what competencies the students should achieve. They may question whether or not students' participation in the process of assessment would be beneficial. Honest teachers would admit that the idea of democratic assessment makes them feel insecure. Quite often, teachers do not have the training they need in developing assessment instruments that document student learning (Long, 1985; Stiggins, 1987; Herman, Aschbaker, \& Winters, 1992).

To be able to develop democratic assessment practices, teachers must have access to professional development opportunities that will help them learn to design and use assessments that can endorse student achievement. Mere exposure to assessment theories and examples of innovative instruments is not enough, neither are one-shot workshops. Teachers should be engaged in long-term, collaborative activities with their colleagues in which they get feedback about their tests and evaluation instruments from their students, colleagues, administrators, and those who are experienced in using democratic assessment for learning.

\section{Conclusion and Recommendation}

Thus, this article offers only a launching point, a place to begin the discussion about how to involve students in their own learning process in literary classrooms. It documents the beginning of teaching journey: a course in which every teacher collaborates with other language teachers in the assessment of their students' performance. Though it only offers an alternative way of doing the assessment, it provides an objective insight toward the nature of communication democratically, with which it eventually building up the students' communicative competence.

Therefore, there are some points to consider in relation with the teaching and learning methodology regarding democracy in language assessment. Firstly, teacher and the curricular provider should be able to identify and define the terms of the learning outcomes. This is an important aspect to point out since the goal of the teaching process is the orientation which will be taken into consideration. Secondly, the institution should clarify the standard to be achieved. This will determine the color of the education it may take for the students and the stakeholders. Last but not least, the institution should monitor the progress toward that standard. The institution should consider the long term goal if they want to maintain valuable respond both by parents and stakeholders.

\section{References}

Dewey, J. (1903). "Democracy in Education" in The Elementary School Teacher, Volume IV Number 4, downloaded from 061.005.101.097 on February 24, 2018 02:19:50 AM, from http://www.journals.uchicago.edu/t-and-d 
INTERNATIONAL JOURNAL OF ACADEMIC RESEARCH IN PROGRESSIVE EDUCATION AND

DEVELOPMENT

Vol. 7, No.1, January 2018, E-ISSN: 2226-6348 @ 2018 HRMARS

Herman, J. L., Aschbacher, P. R., \& Winters, L. (1992). A Practical Guide to Alternative Assessment. Alexandria, VA: Association for Supervision and Curriculum Development.

Iberri-Shea, G. (2009). “Using Public Speaking Tasks in English Language Teaching", English Teaching Forum 47 (2): 18-36.

Long, M. H. (1985). "A Role for Instruction in Second Language Acquisition: Task-Based Training", In K. Hyltenstam \& M. Pienemann (Eds.), Modelling and Assessing Second Language Acquisition. Clevedon, Avon: Multilingual Matters, pp. 77-100.

Lytovchenko I. (2009). "How to Make Upper-Level University English Classes More Interactive", English Teaching Forum 47(2): 24-29

Mustofa, A. (2016). "Literary Teaching and Its Constraints: Paradigms and Problems", English Review Journal, 4(2), 219-230

Oscarson, A. D. (2009). Self-Assessment of Writing in English as a Foreign Language. Goteborg, Sweden: ACTA Universitatis Gothenborgensis. ERIC DRS ED505960.

Shohamy, E. (2001). "Democratic assessment as an alternative", Language Testing, 18 (4) 373391

Spigelman, C. (2005). Reconstructing Authority: Negotiating Power in Democratic Learning Sites, in On Location, pp. 185-204, downloaded from 61.5.101.97 on Tuesday 27 Feb 2018 13:45:04 UTC, http://about.jstor.org/terms

Stiggins, R. J. (1987). "Design and development of performance assessments", in Educational Measurement: Issues and Practice, 6(3), 33-42.

Tully, M. (2009). "Mind Mirror Projects: A tool for Integrating Critical Thinking into the English Language Classroom", English Teaching Forum 47 (1): 10-17.

Zakian, M. Moradan, A. \& Naghibi, S.E. (2012). The Relationship of Self-, Peer-, and Teacher Assessments in the Speaking of EFL Learners. ERIC DRS 530967. 